\title{
The annual cycle of the White-ruffed Manakin Corapipo leucorrhoa, a tropical frugivorous altitudinal migrant, and its food plants
}

\author{
LORETA ROSSELLI
}

\section{Summary}

Frugivorous White-ruffed Manakins Corapipo leucorrhoa (Pipridae) showed pronounced seasonal emigration from a pre-montane wet forest site $(550 \mathrm{~m})$ on the Atlantic slope of Costa Rica. "Resident" breeders left the area between August and October, and returned between February and April, at the onset of the breeding season. Female patterns differed from those of males primarily in later departure (October) and later return (April). I documented 57 fruit species in the diet at this locality and monitored phenology for 43 of those species, many of which were understorey members of the Melastomataceae. The emigration did not coincide with a period of local fruit shortage (relative to abundance at the same locality in other months), but the relative abundance and species composition of fruit resources in the areas to which the manakins migrated remains unknown. However, peak resources did coincide with the period in which recent fledglings would be commonest and the period during which most individuals were moulting prior to emigration. Resources were lowest from November, when residents were absent, until June, well into the breeding season. Tentative evidence suggests considerable annual variation, possibly owing to differences in the timing of the rainy season. Individuals captured during the period when almost all "resident' breeders were absent (November) appeared to be transients, and were rarely recaptured. Weights differed between sexes, with females $(\chi=12.5 \pm 1.0)$ significantly heavier than males $(\chi=11.1 \pm 0.8)$. Males were lightest during the breeding season, intermediate in weight during the moulting period, and both sexes were heaviest during the migration period, when they accumulated subcutaneous fat. Females were lightest during the moult period, at which time many may also have dependent fledglings. Many other frugivores and nectarivores may engage in similar altitudinal migrations. Even where altitudinal migration is not possible, birds might migrate to other habitats with different fruit resources or phenologies. The design of nature reserves should accommodate the possibility of significant altitudinal (or cross-habitat) migration for many species of frugivores and nectarivores.

Los saltarines gorgiblancos Corapipo leucorrhoa (Pipridae) presentaron una pronunciada emigración estacional de una localidad a $55^{\circ} \mathrm{m}$ de altura en un bosque 
pluvial premontano en la vertiente atlántica de Costa Rica. Los residentes reproductores abandonaron el área entre agosto y octubre, regresando entre febrero y abril, a comienzos de la época reproductiva. El patrón de emigración y regreso al área de las hembras difirió del de los machos principalmente en una salida y regreso más tardíos (octubre y abril respectivamente). Encontré 57 especies de frutos en esta localidad en la dieta de estos saltarines y pude hacer seguimiento fenológico de 43 de éstos, muchas de las cuales son plantas del sotobosque de la familia Melastomataceae. La emigración no coincidió con una época de escasez (en relación a la abundancia de frutos en otros meses en la misma localidad), aunque se desconoce la abundancia y composición de los frutos de las áreas hacia las cuales emigraron. Sin embargo, la época de abundancia de recursos si coincidió con el período anterior a la emigración, en que había mayor abundancia de polluelos recién eclosionados y la mayoría de individuos estaba mudando. Los recursos fueron más escasos desde noviembre (cuando los residentes estaban ausentes), hasta junio, cuando ya se encontraba bien avanzada la época reproductiva. Hay evidencias que sugieren la existencia de una considerable variación interanual, posiblemente debido a las diferencias en la ocurrencia de la época lluviosa. Los individuos capturados en la época en que casi todos los "residentes" estaban ausentes (noviembre) parecían ser transeúntes y presentaron bajas tasas de recaptura. El peso fue diferente entre los dos sexos ya que las hembras resultaron significativamente más pesadas $(\bar{x}=12.5 \pm 1.0)$ que los machos $(\bar{x}=11.1 \pm 0.8)$. Los machos presentaron su peso mínimo en la época reproductiva, tuvieron un peso intermedio durante la muda y los dos sexos presentaron el mayor peso en la época de migración, durante la cual acumularon grasa subcutánea. Las hembras presentaron el peso más bajo durante la época de muda, la cual coincidió con la mayor cantidad de pollos dependientes. Es posible que muchas otras aves frugívoras y nectarívoras realicen migraciones altitudinales semejantes. Inclusive en donde no es posible que se dé la migración altitudinal, las aves pueden moverse a otros hábitats con diferente oferta de frutos o fenología. El diseño de las áreas de reserva naturales debería incluir la posibilidad de migraciones altitudinales para muchas especies de frugivoros y nectarívoros.

\section{Introduction}

The tropics were long considered areas of great stability, where food was abundant year-round; this was considered one of the causes of high tropical species diversity, since organisms had more time to evolve in complicated forms (Fischer 1960, Orians 1969, Leigh 1990). However, numerous recent studies have gradually shown the idea incorrect: virtually all tropical systems studied to date have shown a marked seasonality with periods of great resource scarcity causing stress in animals (Charles-Dominique et al. 1981, Dinerstein 1986, Gauthier-Hion et al. 1985, Giacalone et al. 1990, Milton 1990, Smythe 1990).

In the case of frugivorous birds, these periods of scarcity are known to cause changes in diet (Foster 1977, 1982a,b, Leighton and Leighton 1983, Terborgh 1986a,b, Worthington 1990), in habitat (Levey 1988), and emigration from the area (Leighton and Leighton 1983, Wheelwright 1983, Terborgh 1986a,b, Levey 1988, Worthington 1990, Loiselle and Blake 1991). A particular case is altitudinal migration, in which regular movements between two elevations occur, presum- 
ably in frugivores as a response to changes in fruit abundance. In the Neotropics the phenomenon has been studied in some detail in Costa Rica (Slud 1960, Wheelwright 1983, Stiles 1985, Loiselle 1987, Levey 1988, Loiselle and Blake 1991, Levey and Stiles this symposium), although it may be a common event in other tropical mountains (Davis 1945, Ramos 1983, Hilty and Brown 1986). In a study on Costa Rica's Caribbean slope Stiles (1985) found that of the 345 resident forest birds of the area, 25\% migrated altitudinally. As the migrants were almost exclusively nectar- or fruit-eating birds, it is probable that these migrations were linked to changes in availability of these particular food types. Levey (1988) and Loiselle and Blake (1991) have studied frugivore communities, and found evidence of migration as a response to fruit availability. However, these studies only treat the community as a whole, without considering in detail that different species of birds might prefer different fruits (Loiselle and Blake 1990), which in turn might show different seasonal patterns of abundance. The only study to examine in detail how the availability of a bird's preferred fruit affects altitudinal movements is that of Wheelwright (1983) on the Resplendent Quetzal Pharomachrus mocinno. The Quetzal is a specialist on fruits of a single family, the Lauraceae (Wheelwright 1983), and is thus not typical of frugivorous birds as a whole, many of which have much more varied fruit diets. There is thus a need for more detailed studies of particular species of migratory frugivorous birds and the fruits on which they depend.

The pattern of altitudinal migration is similar in all species of frugivorous birds on Costa Rica's Atlantic slope: the birds breed at higher elevations, with nesting activity tending to peak in April or May; following the reproductive season there is a gradual downward movement between about July and October. The birds remain at lower elevations until toward the end of January, and ascend to the breeding grounds between February and March (Stiles 1988, Loiselle and Blake 1991). Little is known about the details of migration in these species, although a number of them can be found year-round at intermediate elevations (Stiles and Skutch 1989). Several possibilities exist to explain this pattern: populations breeding at higher elevations are migratory while those at the lower end of the breeding range are sedentary, producing a "leapfrog" migration; or the entire species population could simply shift downhill, producing turnover of individuals at intermediate elevations. Migration could also be complete (all individuals abandon the reproductive area for several months), or partial (not all individuals abandon the area), among other possibilities (Levey 1988, Loiselle and Blake in prep.).

My objective was to study in detail a frugivorous altitudinal migrant along with its most important fruit plants at a site near the middle of the bird's altitudinal range, to determine how fruit availability might be related to population movements, breeding and moult. Through a year-long banding study, I hoped to document migration patterns in detail.

\section{Methods}

\section{Study species}

The White-ruffed Manakin, like other members of the family Pipridae, is highly frugivorous; males perform "dances" over fallen mossy logs (Skutch 1967, 
Rosselli et al in prep.). Adult males are glossy blue-black with a white throat patch; females and first-year males are olive-green, usually with a greyish tint on the throat. Through recaptures of banded birds, I found that a distinct second-year plumage, with a black mask and a partially white throat, exists in males. The sexes are similar in size, but $I$ found that females are significantly heavier than males and first-year individuals of unknown sex (12.5 $\pm 1.0 \mathrm{~g} \mathrm{SD}$, $\mathrm{n}=30$ vs. $11.1 \pm 0.8 \mathrm{~g}, \mathrm{n}=87,11.71 \pm 0.8 \mathrm{~g}, \mathrm{n}=57$, respectively; ANOVA, $\mathrm{F}=31.36, \mathrm{P}<0.001, \mathrm{df}=2,171)$. The species inhabits lower and middle levels of dense wet forests from south-east Honduras to north-west Venezuela, and from sea level to $1,500 \mathrm{~m}$ (Stiles and Skutch 1989). It does not form permanent pairs. Females construct the nest, incubate the two eggs and raise the young by themselves. On Costa Rica's Caribbean slope C. leucorrhoa is most abundant at elevations of approximately $500 \mathrm{~m}$, and nests between 400 and $800 \mathrm{~m}$ (Stiles and Skutch 1989), although it occasionally reaches $1,000 \mathrm{~m}$. In the nonreproductive period, part of the population migrates downward as documented by the regular appearance of $C$. leucorrhoa (otherwise absent) at La Selva Biological Station ( $50 \mathrm{~m}$ ) in the last months of the year (Slud 1960, Levey 1988, Stiles and Skutch 1989, Loiselle and Blake 1991, F. G. Stiles unpublished data). In these same months $C$. leucorrhoa disappears from the higher elevations of its distribution. In Costa Rica C. leucorrhoa has been briefly studied by Skutch (1967) on the Pacific slope and as part of broader studies by Loiselle (1987), Loiselle and Blake (1990, 1991) and Levey (1988).

\section{Study site}

I conducted this study between July 1987 and July 1988 at Finca El Plástico, a private biological reserve owned by Selva Tica S.A. $12 \mathrm{~km}$ south-east of Las Horquetas de Sarapiqui, Heredia province, Costa Rica (Figure 1). The reserve is covered mostly by mature forest (pre-montane wet forest sensu Holdridge: Tosi 1969). Among the common canopy trees are Vochysia spp., Carapa guianensis and Guarea spp.; in the understorey shrubs and treelets of Rubiaceae and Melastomataceae are especially abundant; palms are frequent in both canopy and understorey (for a more detailed description of forest in the area see Hartshorn and Peralta 1988). The reserve borders Rara Avis, another private reserve, to the south, and Braulio Carrillo National Park to the west. Thus it is part of a forested area of nearly 44,000 ha that extends from La Selva $(50 \mathrm{~m})$ to the top of Volcán Barva $(2,900 \mathrm{~m}$, Figure 1). The particular 12 ha study area was located in mature forest, between 500 and $600 \mathrm{~m}$. The 12 ha were criss-crossed with a grid of trails $50 \mathrm{~m}$ apart. The area contained a wide diversity of microhabitats, including closed forest, treefall gaps of various sizes and ages, creeks of different sizes, ravines and ridges. Other common understorey frugivore birds included Olive Tanager Chlorothraupis carmioli, Tawny-crested Tanager Tachyphonus delatrii and Tawnycapped Euphonia Euphonia anneae. Other manakins, although scarce, included Red-capped Manakin Pipra mentalis, White-crowned Manakin P. pipra, Greyheaded Piprites Piprites griseiceps and Thrush-like Manakin Schiffornis turdinus. No rainfall data are available for the site although, according to those of Hartshorn and Peralta (1988) for a nearby area, annual rainfall should be 

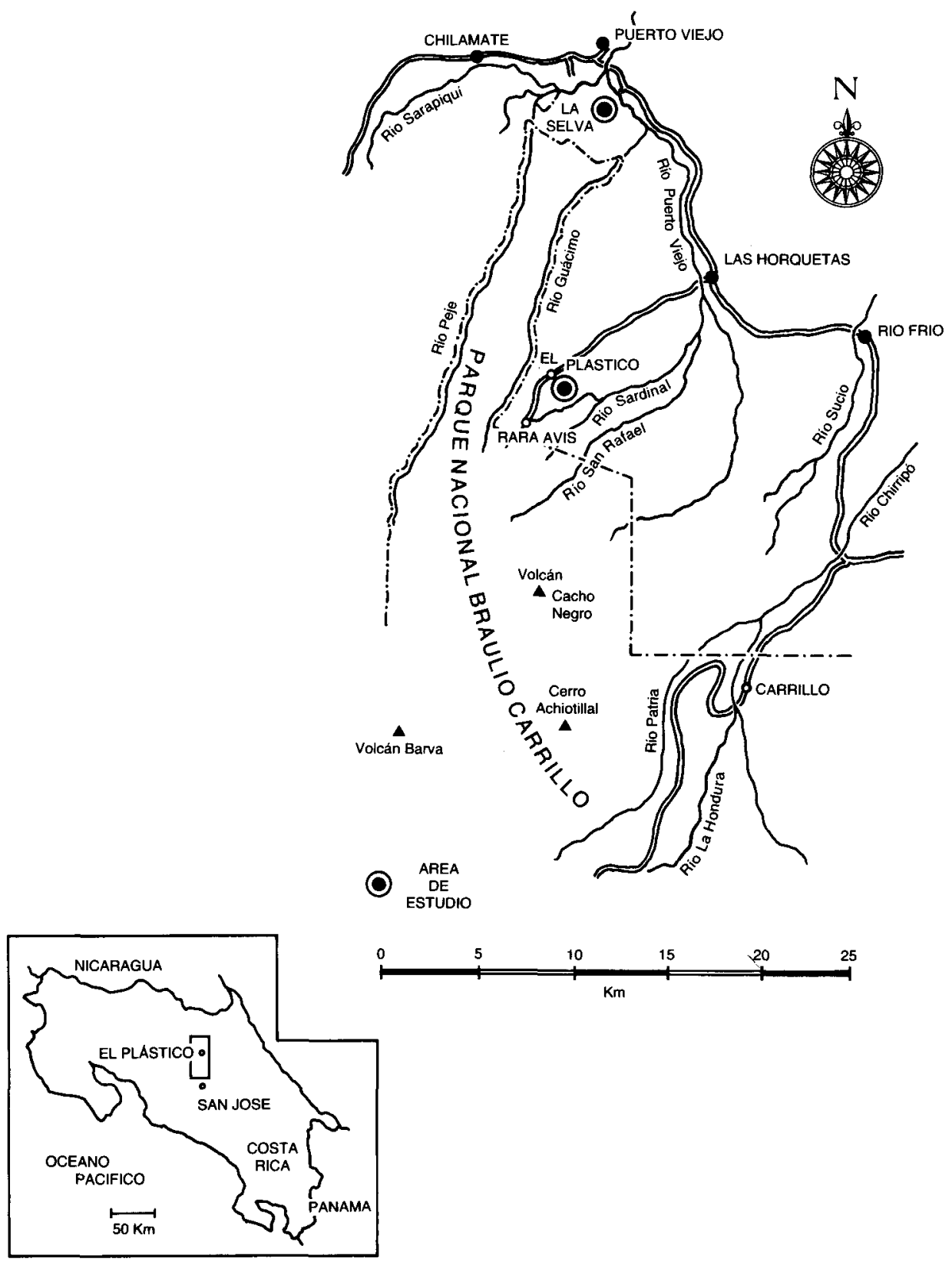

Figure 1. Location of the El Plástico study area in Costa Rica, in relation to Braulio Carrillo National Park and La Selva Biological Station.

close to $5,000 \mathrm{~mm}$, with a pattern similar to that of La Selva, $12 \mathrm{~km}$ north of El Plástico. A dry season between January and April or May is followed by rains during the rest of the year, peaking in July. At La Selva in the year of the study, the first portion of 1988 (January-June) was somewhat wetter than average, and April and June were very dry. 
I estimated fruit abundance through monthly counts except December 1987 (the interval between the censuses of November 1987 and January 1988 was six weeks) of mature and immature fruits potentially consumed by birds, up to a height of $10 \mathrm{~m}$, along $1,700 \mathrm{~m}$ of trails in the study area. The censuses were done in three routes that included the different habitats in the area. The distance on each side of the trails on which fruits were counted was variable, depending on the visibility of the species. Most strips were $2 \mathrm{~m}$ wide on each side, making the total sample area close to $7,000 \mathrm{~m}^{2}$ for most species. When studying fruits as a resource for birds, this kind of quantitative area-based sampling facilitates comparison with other studies and estimates of biomass (Blake et al. 1990). Voucher specimens and samples of all species of fruit were collected for identification, dry fruit weight, and as a reference collection.

Owing to the difficulty in separating pulp from seeds in many species with tiny seeds, the fruit abundance measurement used was fruit dry weight (including seeds). This may cause abundance of large-seeded fruits to be overestimated relative to fruits with small seeds; however, most of the fruits included in this study had fairly similar characteristics, such that biases of this sort are probably minor. Although all fruits potentially consumed by birds were included in the counts, only those for which consumption by $C$. leucorrhoa was confirmed were included in the analyses. The presence of fruits in the canopy was recorded through the presence of fallen fruits on the ground, or estimated from F. G. Stiles's observations of flowering phenology of certain epiphytes, which were made in a simultaneous study.

In the same study area, 20-25 12-m long, $30 \mathrm{~mm}$ mesh mist-nets were set for two to three days every month. Mist-nets were opened from dawn to 13hoo, and were closed during heavy rains. Each C. leucorrhoa caught was put in a round-bottomed bag lined with filter paper to collect faecal samples. Additional gut contents were obtained (especially when birds did not defecate during c. 20 minutes in the bag) by injecting saline solution into the stomach through a feeding tube (Moody 1970). All samples were dried on filter paper and saved for later analysis. Birds were individually colour-banded with A. C. Hughes plastic rings. Age, plumage, reproductive status, fat accumulation (using a $0-4$ scale in which $0=$ no fat, $4=$ heavy deposits over most body areas) and weight were noted. Faecal samples were analysed later with a dissecting microscope and the aid of the seed reference collection. All items present in the samples, including insect parts and nitrogenated remains, were given a quantitative percentage value in the sample. Although this method is quite efficient in sampling frugivorous birds' diets in tropical forests (Snow 1962a, Wheelwright et al. 1984, Loiselle and Blake 1990), faecal sample analysis might be biased by the different passage rates of each food item (Moody 1970, Jordano and Herrera 1981, Levey and Karasov 1992) or the difference between the gut passage and regurgitation of seeds of different sizes (Levey 1987), such that large seeds might be under-represented. I tried, however, to reduce this bias by carefully checking for seeds under mist-netted birds and giving more importance to larger samples in the analysis (see Stiles and Rosselli 1993). 


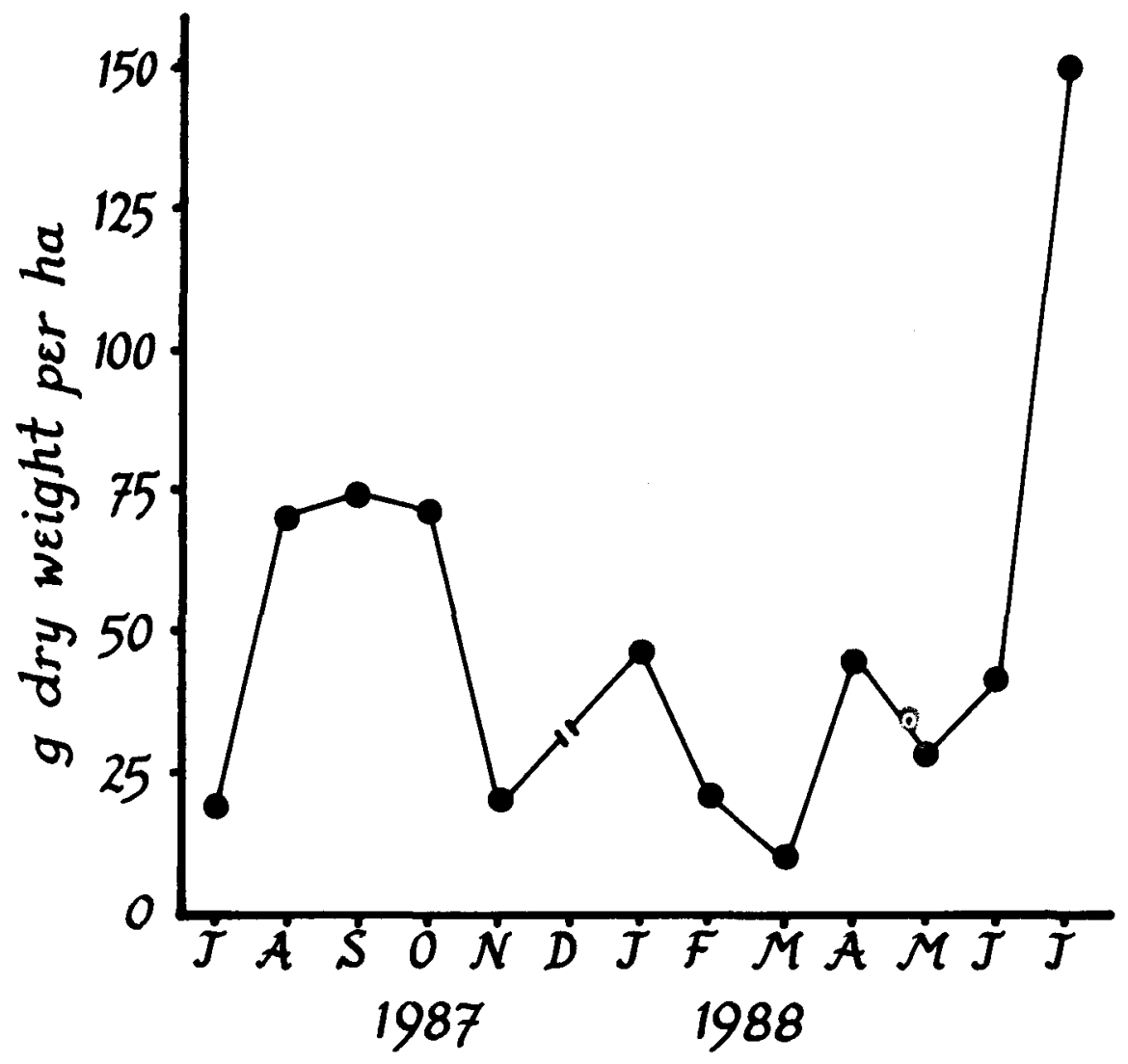

Figure 2. Dry weight per hectare of ripe fruits of all species consumed by Corapipo leucorrhoa at El Plástico during each month of the study (no data are available for December 1987).

\section{Results}

\section{Fruit availability}

I found 150 species of fruit potentially consumed by birds in the study area. For 57 of these I obtained evidence of consumption by C. leucorrhoa, and monitored the phenology of 43 of them (see below). The availability of fruits (all results hereafter refer only to the 43 species studied phenologically, unless otherwise noted) fluctuated greatly throughout the year (Figure 2). There was a period of abundance between August and October 1987 (dry weight per ha $>60 \mathrm{~g}$ ) and one of relative scarcity from November 1987 to June 1988. The values are especially low in November, February and March. July 1988 was a month of great abundance, with more than $140 \mathrm{~g}$ dry fruit weight per ha. This abundance was quite different from that of July 1987 (Figure 2). It is possible that the peak fruiting period of 1988 was delayed 1-2 months relative to that of the previous year owing to exceptionally dry weather in April. Dry fruit weight was significantly correlated with number of ripe fruits per hectare per month 
$\left(r_{s}=0.78, P<0.01\right)$, but not with the number of species with mature fruits per month $\left(r_{s}=0.60, P=0.15\right)$. In all months, non-censused ripe fruits of species potentially consumed by $C$. leucorrhoa were present in the canopy. Most of these species belonged to the Ericaceae and Gesneriaceae, which were consumed by C. leucorrhoa but in low proportions.

\section{Captures}

In 3,953 net-hours during the 12-month study period, C. leucorrhoa was the most frequently captured species among 88 , and represented $16 \%$ of the 1,797 captures (Table 1 ). The monthly number of $C$. leucorrhoa captured per net-hour fluctuated between 0.042 in June and November and 0.151 in March $(\bar{x}=0.072$, $\mathrm{SD}=0.028$ ) (Table 1 ).

There was no significant correlation between $C$. leucorrhoa captures per nethour and fruit abundance $\left(r_{s}=0.07, P>0.05\right)$. Males far outnumbered females in the 219 captures in which sex could be determined ( 169 vs. $59, \chi^{2}=45.66$, $\mathrm{P}<<0.001, \mathrm{Idf}$ ). This tendency was maintained during the breeding, moulting and migration periods, but it was stronger during migration and moult $\left(\chi^{2}=4.06, \quad 0.025<\mathrm{P}<0.05 ; \quad \chi^{2}=9.13, \quad 0.001<\mathrm{P}<0.01 ; \quad \chi^{2}=35.78\right.$, $\mathrm{P}<<$ oo.1) respectively.

February is especially noteworthy, since of 27 individuals captured 26 were males.

Of the 179 banded individuals, 48 were recaptured later at least once. The recapture values - (number of recaptures subsequent to date of first capture multiplied by 10,000) over (number of captures on date of first capture multiplied by number of net-hours subsequent to month 1) - show that the most frequently recaptured individuals were those banded in July 1987 and April 1988 (Figure 3). Birds banded in September, November and March were the least recaptured individuals (Figure 3).

Table 1. Mist-net hours, Corapipo leucorrhoa captures and total captures during the 12-month study period in El Plástico (1987-1988)

\begin{tabular}{lcccc}
\hline & Mist-nest hours & $\begin{array}{c}\text { C. } \\
\text { leucorrhoa } \\
\text { captures }^{1}\end{array}$ & $\begin{array}{c}\text { Total birds } \\
\text { captured }\end{array}$ & $\begin{array}{c}\text { C. leucorrhoa } \\
\text { per 1oo mist-net } \\
\text { hours }\end{array}$ \\
\hline Jul & 197 & 15 & 106 & 7.61 \\
Aug & 280 & 20 & 153 & 7.14 \\
Sep & 195 & 17 & 92 & 8.72 \\
Oct & 371 & 16 & 167 & 4.31 \\
Nov & 185 & 8 & 88 & 4.32 \\
Jan & 241 & 18 & 84 & 7.47 \\
Feb & 320 & 27 & 153 & 8.44 \\
Mar & 398 & 60 & 201 & 15.08 \\
Apr & 390 & 23 & 174 & 5.90 \\
May & 424 & 24 & 201 & 5.66 \\
Jun & 502 & 21 & 174 & 4.18 \\
Jul & 450 & 35 & 204 & 7.78 \\
TOTAL & 3,953 & 284 & 1,797 & \\
\hline
\end{tabular}

${ }^{1}$ Includes first captures and recaptures. 


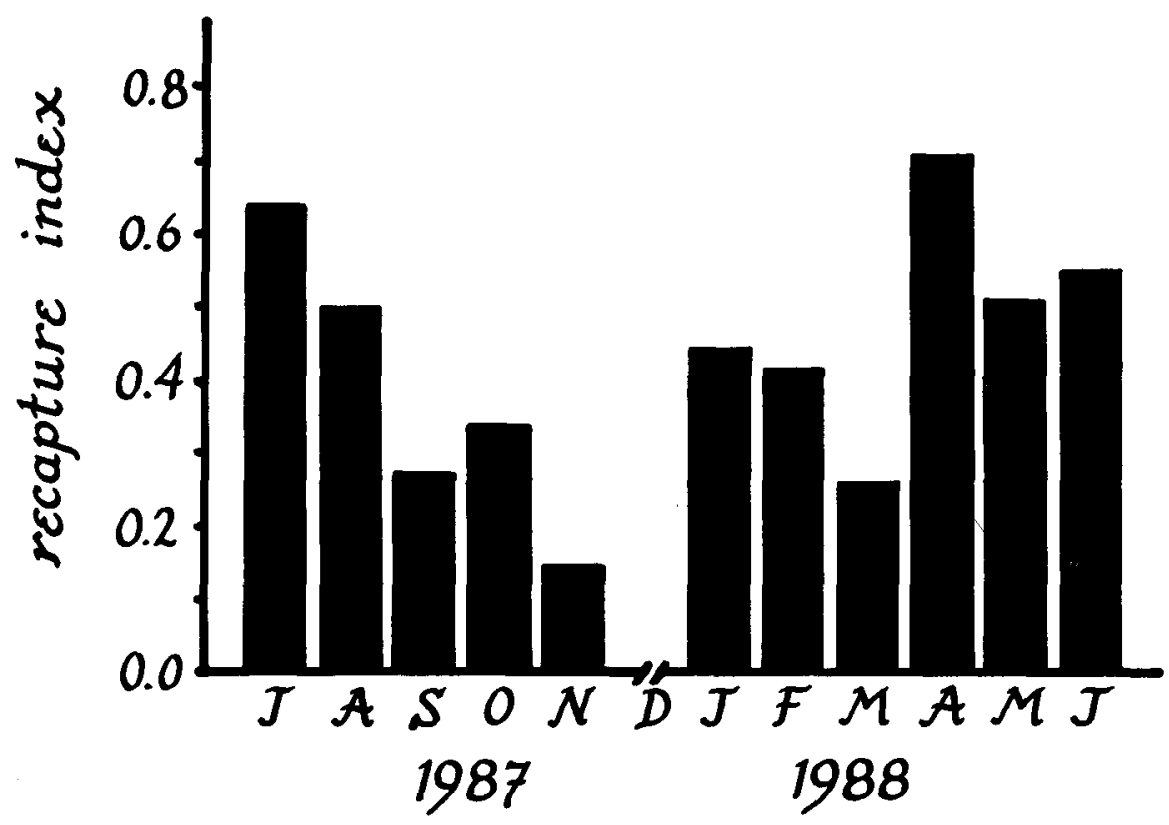

Figure 3. Index of subsequent recaptures for individuals of Corapipo leucorrhoa captured in each month of the study. See text for definition of recapture index. (No netting took place in December 1987.)

Of the 60 individuals banded in 1987,24 (which I call "residents") were regularly captured in 1987 and were recaptured again in 1988. By looking at the individual history of each of these birds (Table 2), it appears that 19 of them left the area since they were not captured for three or more sampling periods (at least four months if it is considered they were also absent in December) between the end of 1987 and the beginning of 1988. None of these individuals was absent for such a long period of time at any other season. The 14 males in this group left the area (were captured for the last time) between July and October, mainly in August. Females tended to "leave" the area later, mainly in October, but this difference is not significant (Kolmogorov-Smirnov two-sample test, $\mathrm{D}_{\max }=0.50, \mathrm{P}=0.10$ ).

The period of "arrival" (first recapture after an absence of several months) extended from January to June (most in March and April) for females; returns of males were more concentrated between January and April, with a peak in February (Table 2). For these arrival data, six additional individuals, which were not caught in 1987 but arrived at the beginning of 1988 and stayed through the breeding season, were included. Neither was there any significant difference between the sexes for arrival date $\left(\mathrm{D}_{\max }=0.33, \mathrm{P}>0.05\right)$.

The five individuals that did not leave the area for three or more consecutive sampling periods included a second-year male (band-code d-rr, who died in February 1988), a first-year male (i-rg), two females (i-rb and i-ow) and an individual of unknown sex and age (d-kk) (Table 2). Male d-rr was the only bird that stayed in the area through the whole migration period. Birds i-rg and i-ow 
Table 2. Capture frequency $(\mathrm{X})$ of the 24 Corapipo leucorrhoa banded in 1987 and recaptured in 1988 (there was no mist-netting in December 1987). $m=$ male; $f=$ female; $u=u n k n o w n ~ s e x ; ~ t=$ the bird died during that month

\begin{tabular}{|c|c|c|c|c|c|c|c|c|c|c|c|c|c|}
\hline $\begin{array}{l}\text { Band- } \\
\text { code }\end{array}$ & Sex & $\begin{array}{l}\text { Jul } \\
87\end{array}$ & $\begin{array}{c}\text { Aug } \\
87\end{array}$ & $\begin{array}{c}\text { Sep } \\
87\end{array}$ & $\begin{array}{l}\text { Oct } \\
87\end{array}$ & $\begin{array}{c}\text { Nov } \\
87\end{array}$ & $\begin{array}{c}\text { Jan } \\
88\end{array}$ & $\begin{array}{c}\text { Feb } \\
88\end{array}$ & $\begin{array}{c}\text { Mar } \\
88\end{array}$ & $\begin{array}{c}\text { Apr } \\
88\end{array}$ & $\begin{array}{c}\text { May } \\
88\end{array}$ & $\begin{array}{c}\text { Jun } \\
88\end{array}$ & $\begin{array}{l}\text { Jul } \\
88\end{array}$ \\
\hline d-rb & $\mathrm{m}$ & $x$ & $x$ & $x$ & & & & $x$ & $x$ & $x$ & $X$ & & $x$ \\
\hline d-rr & $\mathrm{m}$ & $x$ & $x$ & & $x$ & & $x$ & $x+$ & & & & & \\
\hline d-pg & $\mathrm{f}$ & $X$ & $x$ & & $x$ & & & & & $x$ & & $x$ & \\
\hline d-ro & $\mathrm{m}$ & $X$ & $x$ & & & & $x$ & $x$ & $x$ & $X+$ & & & \\
\hline d-rp & $\mathrm{f}$ & $x$ & & & & & $x$ & & $x$ & $x$ & $x$ & $x$ & \\
\hline d-rk & $\mathrm{m}$ & $x$ & & & & & $x$ & & $x$ & & & & \\
\hline d-pp & $\mathrm{m}$ & $X$ & & & & & & $x$ & & $x$ & $x$ & & \\
\hline d-go & $\mathrm{f}$ & & $x$ & & $x$ & & & & & $x$ & & & \\
\hline d-oc & $\mathrm{f}$ & & $x$ & & & & $x$ & & & $x$ & $x$ & $x$ & \\
\hline d-wc & $\mathrm{m}$ & & $x$ & & & & & $x+$ & & & & & \\
\hline d-ob & $\mathrm{m}$ & & $x$ & & & & & & $x$ & & $x$ & & \\
\hline d-bg & $\mathrm{m}$ & & $x$ & & & & & & $x$ & & & & \\
\hline $\mathrm{d}-\mathrm{bb}$ & $\mathrm{m}$ & & $x$ & & & & & & & $x$ & & $x$ & \\
\hline d-kw & $\mathrm{f}$ & & $x$ & & & & & & & & $x$ & & \\
\hline i-pr & $\mathrm{m}$ & & & $X$ & & & & $x$ & & $x$ & $x$ & & \\
\hline $\mathrm{d}-\mathrm{cb}$ & $\mathrm{m}$ & & & $x$ & & & & & $x$ & $x$ & $x$ & & \\
\hline $\mathrm{d}-\mathrm{kk}$ & $\mathfrak{u}$ & & & $X$ & & & & & $x$ & & & & \\
\hline d-bk & $\mathrm{m}$ & & & $x$ & & & & & & $x$ & $x$ & & \\
\hline i-rg & $\mathrm{m}$ & & & & $x$ & & & $x$ & & & & & $x$ \\
\hline i-pw & $\mathrm{m}$ & & & & $x$ & & & & $x$ & $x$ & $x$ & & \\
\hline i-rw & $\mathrm{f}$ & & & & $x$ & & & & $X$ & & $x$ & $x$ & \\
\hline i-ro & $\mathrm{m}$ & & & & $x$ & & & & & & $x$ & & \\
\hline i-rb & $\mathrm{f}$ & & & & $x$ & & & & & & & & $x$ \\
\hline i-ow & $\mathrm{f}$ & & & & & $x$ & & & $x$ & & & $x$ & $x$ \\
\hline
\end{tabular}

also seem to have emigrated and may have been residents in nearby areas; $d-k k$ and i-rb were perhaps transients on their own migration routes.

\section{Reproduction and moult}

In 1988 the C. leucorrhoa reproductive season began in March and peaked from April through June, although at the end of the study period in July some birds still showed signs of reproduction (Figure 4). This period, as evidenced by morphological features (presence of vascularized brood-patch and very enlarged cloacal protuberance), corresponds to the time of copulation, egg-laying and incubation. Assuming that females captured with vascularized brood-patches were more or less in the middle of their incubation period, I calculated the approximate time for the presence of nestlings between April and August by adding eight days to the capture date, as the approximate mid-point of incubation, and 16 days as the approximate nestling period for a manakin of this size (Stiles and Skutch 1989). I added 21 more days to estimate the period for maternal feeding of fledglings out of the nest, which would therefore occur between May and September (Figure 4). Although there are no data for manakins in this regard, I have seen C. leucorrhoa females feeding apparently full-grown young outside of the nest, and the assumed period is consistent with data from other tropical passerines (Skutch 1976). 


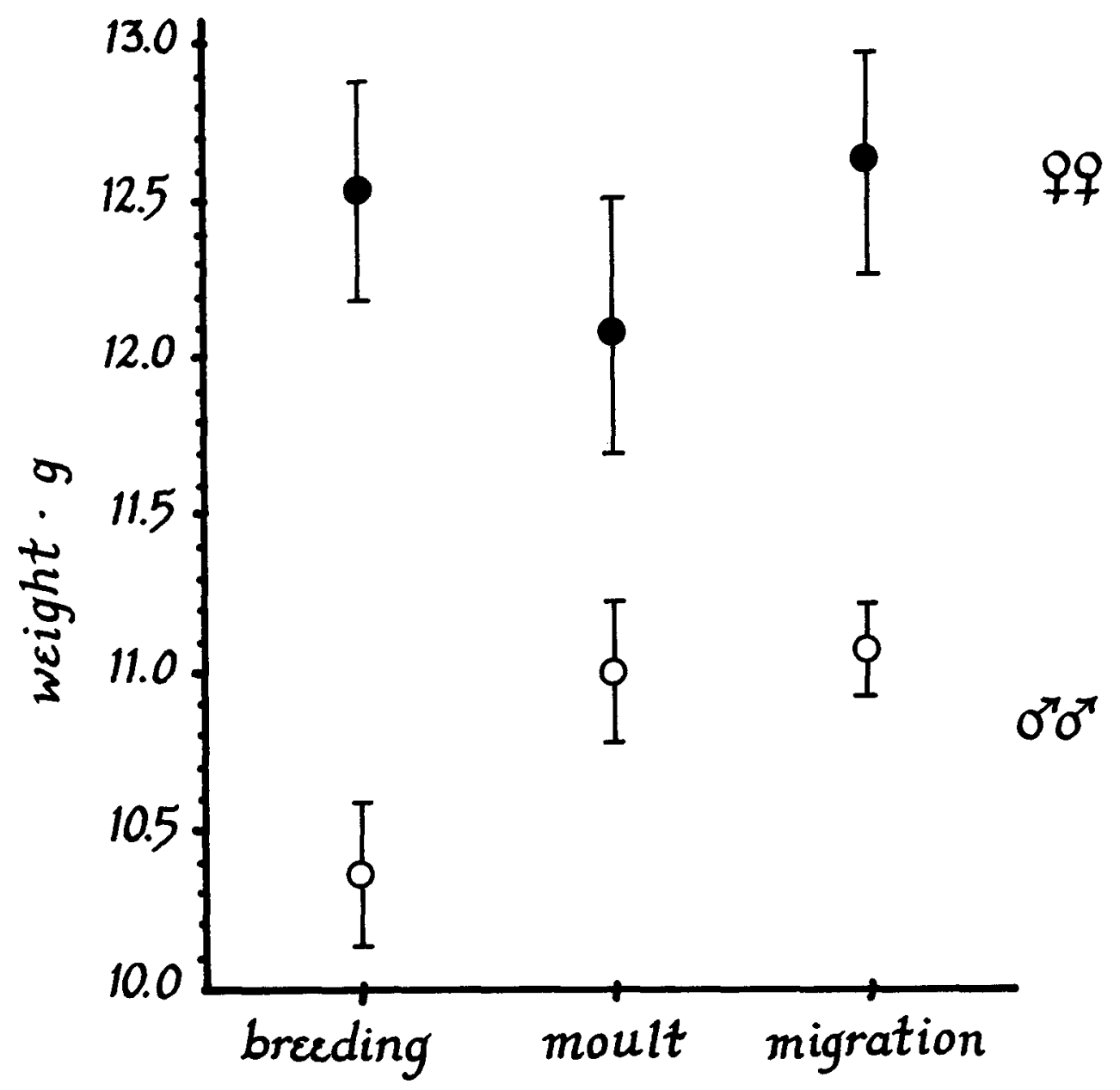

Figure 4. Variation in mean weights ( $\pm 95 \%$ confidence intervals) of female (above) and male (below) Corapipo leucorrhoa between breeding, moult and migration seasons (approximately April-June, July-September and October-March, respectively).

The moulting period for flight-feathers was at a peak at the start of the study in July 1987, and extended until November. Moult began again in May 1988 and apparently had not yet reached its peak in July, at the end of the study period (Figure 4). The initiation of moult of the flight-feathers was followed by a complete moult of the body plumage in individuals at least a year old. The complete process may take from two to three months, according to data obtained from the successive recaptures of moulting individuals.

\section{Diet}

I analysed 263 faecal samples ( 53 from females, 132 from males and 78 from individuals of unknown sex). All samples contained fruit remains and $60 \%$ contained animal remains of some sort. The proportion of animal remains in the 
samples was very low $(\bar{x}=0.11, S D=0.20, n=157)$. Animal remains included insect and spider parts and white nitrogenated remains (the latter might also have come from fruit protein, so if anything the proportion of animal remains might be overestimated).

The difference between the proportion of invertebrate remains in male, female and unknown individuals' samples was significant (Kruskal-Wallis test, $\mathrm{H}=$ 10.53, $\mathrm{P}=0.005, \mathrm{n}=263$ ), with females having the highest values and males the lowest. In females consumption of invertebrates was higher during the breeding season compared to moult and migration periods, whereas in males highest invertebrate consumption was during moult, but seasonal variation was not significant in either case $(\mathrm{H}=2.23, \mathrm{P}=0.33, \mathrm{n}=53 ; \mathrm{H}=3.27, \mathrm{P}=0.19$, $\mathrm{n}=132$ respectively).

Fifty-seven species of plant were found in the faecal samples, most of them belonging to the Melastomataceae (over $70 \%$ of all fruit consumed by volume) and Rubiaceae. Fourteen of the species were not recorded in my censuses, and most probably came from areas of second growth or the canopy. The species most frequently consumed by $C$. leucorrhoa during 1987-1988 were Casearia arborea, Conostegia cooperi, Henriettella tuberculosa, Miconia aff. smaragdina, Oreopanax sp. and Ossaea spp. (includes four species of Ossaea with indistinguishable seeds in samples, mostly Ossaea brenesi). The abundance pattern (dry weight per ha) of these species is similar to the one described for all species consumed by $C$. leucorrhoa $\left(r_{\mathrm{s}}=0.75, \mathrm{P}=0.012, \mathrm{n}=12\right)$. For further data on relative importance in the diet, fruiting phenology, abundance and distribution of these fruits in the study area, see Rosselli (1989).

\section{Weight and fat deposits}

Throughout the year, monthly male weight (which was lower than female weight as noted above) fluctuated significantly (Kruskal-Wallis test, $\mathrm{H}=49.96$, $\mathrm{P}<0.001, \mathrm{n}=158$ ), with a peak from October to January and the lowest values in the period between February and May. Although these periods roughly correspond to the periods of fruit abundance and scarcity, there is no significant correlation between male weight and dry fruit weight $\left(\mathrm{r}^{2}=0.126, \mathrm{P}>0.05, \mathrm{n}=\right.$ 12).

Grouping the data by breeding (April-June, $\mathrm{n}=37$ ), migration (OctoberMarch, $\mathrm{n}=76$ ) and moulting (July-September, $\mathrm{n}=11$ ) periods, the difference in mean male weights is highly significant (ANOVA, $F=8.62, \mathrm{P}<0.001$, $121,2 \mathrm{df}$ ) with the lowest value in the breeding season (Figure 5). Across these same periods fat accumulation also differed significantly, attaining highest values in the migration period $(H=15.90, P<0.001, n=124)$. The pattern of fat accumulation was similar in females, although the differences were not significant $(\mathrm{H}=3.66, \mathrm{P}>0.05, \mathrm{n}=64)$, nor was the weight variation between the three periods (ANOVA, $F=1.37, P>0.05,61,2 \mathrm{df}$ ).

\section{Discussion}

Although C. leucorrhoa was present year-round at the study site, there was emigration of some individuals from the area. Loiselle and Blake (1991) consider 


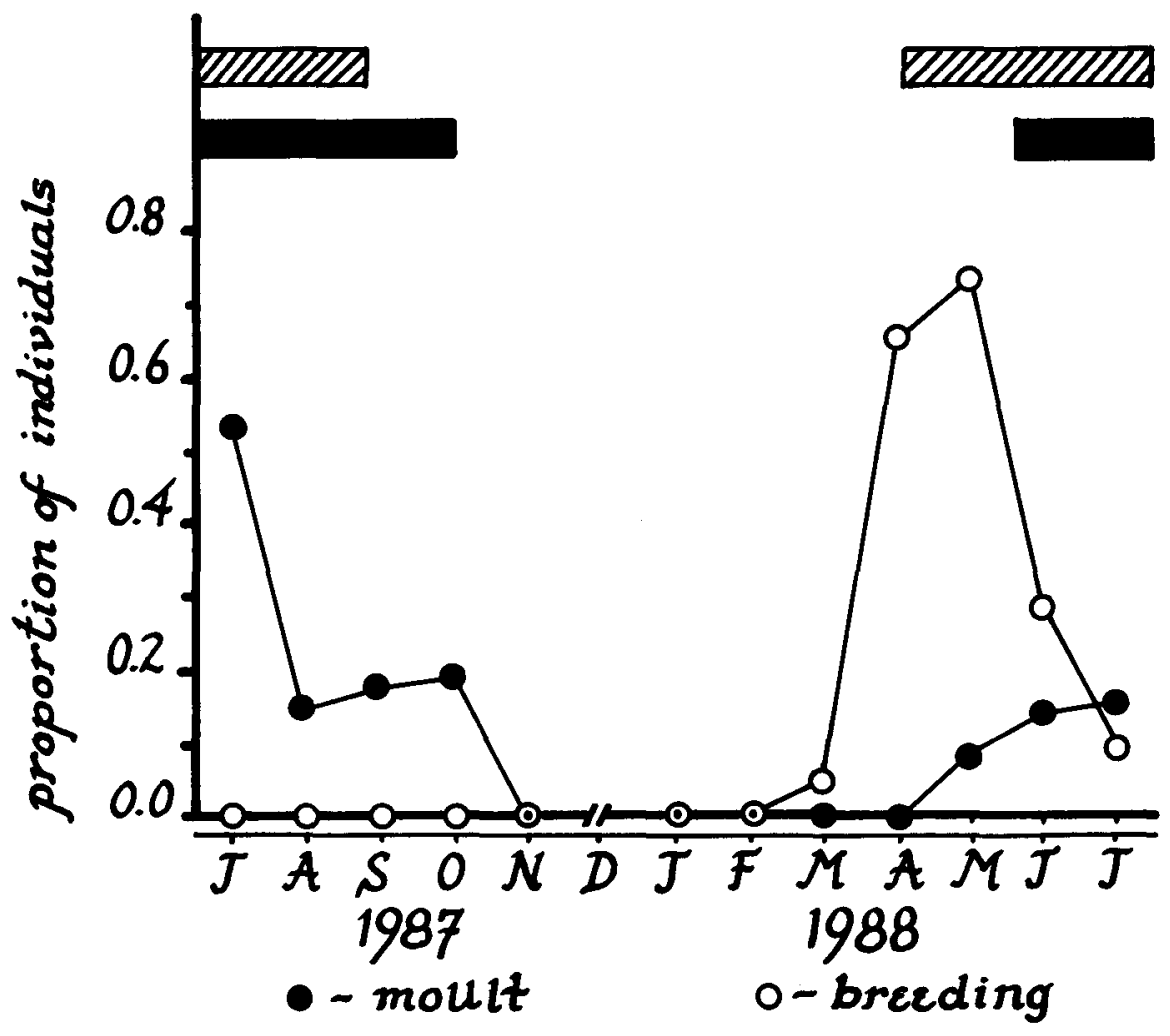

Figure 5. Proportions of captured individuals of Corapipo leucorrhoa with signs of breeding status or moult during each month of the study. Hatched and solid bars at top correspond to approximate periods in which females were feeding nestlings, or caring for fledglings, respectively.

C. leucorrhoa to be a partial altitudinal migrant, in which some members of the population are altitudinal migrants and others $(>20 \%)$ are residents. According to my data, most $C$. leucorrhoa caught in the study site were not permanent residents but rather transients. These individuals might be on their own migration routes or residents in nearby areas. The overall pattern appears to be a general downward shift of the entire population combined with considerable moving about by many, if not most individuals during the non-breeding period.

As shown by diet analysis, White-ruffed Manakins are highly frugivorous all year long (see also Loiselle and Blake 1990), as are most manakins studied so far (Snow 1962a,b, Breitwisch and Pliske 1974, Prum and Johnston 1987, Marini 1992, Stiles and Rosselli 1993). Therefore, the cause of migration may be related to differential changes in fruit abundance at different elevations, as found by Loiselle and Blake (1991). Levey (1988) proposed that breeding seasons of small frugivores such as $C$. leucorrhoa might in fact be related to peaks in insect availability. However, I found that insect consumption by this species was low and did not increase significantly during the breeding period.

At El Plástico, however, the pattern is less obvious, because birds left the area in a time of overall fruit abundance (July-October) and returned and bred 
in a time of overall scarcity (January-June); in fact, the month with highest capture rate of $C$. leucorrhoa, March, had the lowest value of fruit abundance. The fruit abundance during the time in which manakins left the area may be lower than what they could find at lower elevations, where a period of abundance seems to be regular (Opler et al. 1980, Levey 1988, Loiselle and Blake 1991). Unfortunately, however, there are no data available on the abundance of the specific fruits consumed by C. leucorrhoa, comparable to the data from this study.

Although other manakins have been found to reproduce in times of fruit abundance (Snow 1962a, Worthington 1990), Loiselle and Blake (1991) also found that frugivorous birds at three different elevations (50, 100 and $1,000 \mathrm{~m}$ ) on Costa Rica's Caribbean slope bred when fruit abundance was low. Breeding at this time may affect males, as shown by their low weight during these months although hypotheses other than fruit scarcity could also explain weight loss (e.g. increased display activity). Females may also be affected (although their weight loss could be masked by having eggs in formation). Nevertheless, it is probably advantageous for females to start nesting before fruit is abundant, so that the heavy demands of feeding of fledglings and moult occur at a time of abundance (June-August). Several of C. leucorrhoa's favourite foods (Miconia aff. smaragdina, Oreopanax sp., Conostegia cooperi and Henriettela tuberculosa) had their ripening peak in these months, which may mean that at least some of these resources can then be depended on.

Females left the area somewhat later than males, probably owing to their raising young. They apparently also migrated further downslope than males, as evidenced by the higher proportion of females found in the lowlands by several researchers ( 21 males vs. 48 females: D. Levey unpublished data 19821983; 13 males vs. 34 females: F. G. Stiles unpublished data 1971-1988). Resident males also returned sooner to their breeding grounds, very likely to re-establish control of their display areas, which seem to be quite permanent. Some of these residents were seen at the same display logs for three consecutive years (Rosselli et al. in prep.).

This complex and still not totally understood pattern of migration represents just one of the nearly 90 species of altitudinal migrants on Costa Rica's Caribbean slope (Stiles 1985, Loiselle and Blake 1991). Corapipo leucorrhoa, although consuming a wide variety of fruit, depends mainly on a few species at El Plástico. We do not know its feeding patterns at other altitudes. It is a species that depends on deep forest understorey (Stiles 1988, Loiselle and Blake 1991) and might be very vulnerable to extinction owing to habitat alteration. As one of the most abundant species both at the study site and in Loiselle and Blake's (1991) lowland and foothill sites, its disappearance might well affect the structure of the understorey.

The results of this study suggest that designing reserves that incorporate a range of altitudes is very important, particularly considering that the assumption that tropical forest birds are sedentary is still implicit in many conservation studies but may not be true for many frugivores and nectarivores (Stiles and Clark 1989). The forest cover is already highly altered in most Neotropical countries; for example, there is great disparity between available forest areas in the highlands and the lowlands in Costa Rica (being much higher in the former) (Stiles and Clark 1989). In Colombia lowland forest areas cover a far greater 
area than do natural highland habitats (González et al. 1989). We do not know to what extent the patterns of movement we are seeing may have already been affected by habitat alteration in such areas. In fact, the number of species showing altitudinal migration may be considerably greater than we realize, because some movement patterns are subtle and difficult to detect except by careful banding studies (e.g. Levey 1988, Loiselle and Blake 1991 for Pipra mentalis). A corollary is that rapid surveys in limited areas, such as often occur prior to the establishment of a reserve, might miss such species altogether or misinterpret their ecological requirements. Failure to accommodate altitudinal migration when designing reserves may contribute to accelerated loss of avian species and their role in seed dispersal and forest renewal.

\section{Acknowledgements}

I am very grateful to my family for support during my stay in Costa Rica. W. G. Eberhard and R. Soto provided useful comments and suggestions during all stages of this project. I especially thank the staff of Rara Avis for logistical support. J. Blake, D. J. Levey, B. A. Loiselle and F. G. Stiles generously provided their unpublished data. Biologists from the Museo Nacional de Costa Rica identified plant specimens. F. G. Stiles prepared the study area and provided invaluable assistance in the field and throughout the project, including the preparation of the English version and the drawing of the figures. Suggestions by D. J. Levey and D. McDonald greatly improved the final version of the manuscript. This work is part of my M.Sc. thesis at the Universidad de Costa Rica, where financial aid was provided by Vicerrectoría de Investigación, the Organization for Tropical Studies, the National Geographic Foundation and the German Hummingbird Society. I thank the International Council for Bird Preservation and World Wildlife Fund, especially Kimberley Young, for the opportunity to attend the symposium.

\section{References}

Blake, J. G., Loiselle, B. A., Moermond, T. C., Levey, D. J. and Denslow, J. S. (1990) Quantifying abundance of fruits for birds in tropical habitats. Stud. Avian Biol. 13: 73-79.

Breitwisch, R. and Pliske, M. (1974) Anthurium fruit as food of White-bearded Manakins. Ibis 116: 365 .

Charles-Dominique P., Atramentowicz, M., Charles-Dominique, M., Gérard, H., Hladik, A., Hladik, C. M. and Prévost, M. I. (1981) Les mammifères frugivores arboricoles nocturnes d'une forest Guyanaise: inter-relations plantes-animaux. Rev. Ecol. (Terre et Vie) 35: 341-436.

Davis, D. C. (1945) The annual cycle of plants, mosquitos, birds and mammals in two Brazilian forests. Ecol. Monogr. 15: 243-295.

Dinerstein, E. (1986) Reproductive ecology of fruit bats and the seasonality of fruit production in a Costa Rican cloud forest. Biotropica 18: 307-318.

Fischer, A. G. (1960) Latitudinal variations in organic diversity. Evolution 14: 64-81.

Foster, M. S. (1977) Ecological and nutritional effects of food scarcity on a tropical frugivorous bird and its fruit source. Ecology 58: 73-85. 
Foster, R. B. (1982a) The seasonal rhythm of fruitfall on Barro Colorado Island. Pp.151172 in E. G. Leigh, A. S. Rand and D. M. Windsor, eds. The ecology of a tropical forest. Washington, D.C.: Smithsonian Institution Press.

Foster, R. B. (1982b) Famine on Barro Colorado Island. Pp.201-212 in E. G. Leigh, A. S. Rand and D. M. Windsor, eds. The ecology of a tropical forest. Washington, D.C.: Smithsonian Institution Press.

Gauthier-Hion A., Duplantier, J. M., Emmons, L., Feer, F., Heckestweiler, P., Mougazi, A., Quris, R. and Sourd, C. (1985) Coadaptation entre rythmes de fructification et frugivorie en forêt tropicale humide de Gabon: mythe ou realité? Rev. Ecol. (Terre et Vie) 60: 405-434.

Giacalone, J., Glanz, W. E. and Leigh, E. G. (1990) Adición: fluctuaciones poblacionales a largo plazo de Sciurus granatensis en relación con la disponibilidad de frutos. Pp.331335 in E. G. Leigh, A. S. Rand and D. M. Windsor, eds. Ecología de un bosque tropical. Panamá: Smithsonian Tropical Research Institute.

González, E., Guillot, G., Miranda, N. and Pombo, D., eds. (1989) Perfil ambiental de Colombia. Bogotá: Impresora Escala.

Hartshorn, G. S. and Peralta, R. (1988) Preliminary description of primary forests along the La Selva-Volcán Barva altitudinal transect, Costa Rica. Pp.281-296 in F. Almeda and C. M. Pringle, eds. Tropical rainforests: diversity and conservation. San Francisco, CA: California Academy of Sciences.

Hilty, S. L. and Brown, W. L. (1986) A guide to the birds of Colombia. Princeton, NJ: Princeton University Press.

Jordano, P. and Herrera, C. M. (1981) The frugivorous diet of Blackcap populations Sylvia atricapilla wintering in southern Spain. Ibis 123: 502-507.

Leigh, E. G. (1990) Introducción: ¿Por qué hay tantos tipos de árboles tropicales? Pp.7579 in E. G. Leigh, A. S. Rand and D. M. Windsor, eds. Ecologia de un bosque tropical. Panamá: Smithsonian Tropical Research Institute.

Leighton, M. and Leighton, D. R. (1983) Vertebrate responses to fruiting seasonality within a Bornean rain forest. Pp.181-196 in S. L. Sutton, T. C. Whitmore and A. C. Chadwick, eds. Tropical rain forest: ecology and management. Oxford: Blackwell Scientific Publications.

Levey, D. J. (1987) Seed size and fruit-handling techniques of avian frugivores. Amer. Nat. 129: $471-485$.

Levey, D. J. (1988) Spatial and temporal variation in Costa Rican fruit and fruit eating bird abundance. Ecol. Monogr. 58: 251-269.

Levey, D. J. and Karasov, W. (1992) Digestive modulation in a seasonal frugivore, the American Robin (Turdus migratorius). Amer. J. Physiol.

Loiselle, B. A. (1987) Birds and plants in a Neotropical rain forest: seasonality and interactions. Madison, WI: University of Wisconsin (Ph.D. thesis).

Loiselle, B. A. and Blake, J. G. (1990) Diets of understory fruit eating birds in Costa Rica: seasonality and resource abundance. Stud. Avian Biol. 13: 91-103.

Loiselle, B. A. and Blake, J. G. (1991) Temporal variation in birds and fruits along an elevational gradient in Costa Rica. Ecology 72: 180-193.

Loiselle, B. A. and Blake, J. G. (in prep.) Patterns of altitudinal migration by frugivorous birds along a wet forest elevational gradient in Costa Rica.

Marini, M. A. (1992) Foraging behavior and diet of the Helmeted Manakin. Condor 94: 151-158.

Milton, K. (1990) Calidad dietética and regulación demográfica de una población de monos aulladores Alouatta palliata. Pp.357-373 in E. G. Leigh, A. S. Rand and D. M. Windsor, eds. Ecología de un bosque tropical. Panamá: Smithsonian Tropical Research Institute.

Moody, D. T. (1970) A method for obtaining food samples from insectivorous birds. Auk 87: 579 . 
Opler, P. A., Frankie, G. W. and Baker, H. G. (1980) Comparative phenological studies of treelet and shrub species in tropical wet and dry forests in the lowlands of Costa Rica. J. Ecol. 68: 167-188.

Orians, G. H. (1969) The number of species in some tropical forests. Ecology 50: 783-801.

Prum, R. O. and Johnston, A. E. (1987) Display behavior, foraging ecology, and systematics of the Golden-winged Manakin (Masius chrysopterus). Wilson Bull. 99: 521-539.

Ramos, M. A. (1983) Seasonal movements of bird populations at a Neotropical study site in southern Veracruz, México. Minneapolis, MN: University of Minnesota (Ph.D. dissertation).

Rosselli, L. (1989) El ciclo anual de un ave frugívora migratoria altitudinal, Corapipo leucorrhoa (Pipridae), y los frutos que consume. San José, Costa Rica: Universidad de Costa Rica (M.Sc. thesis).

Rosselli, L., Vásquez, P. and Ayub, I. (in prep.) The courtship displays and social system of Corapipo leucorrhoa altera in Costa Rica.

Skutch, A. F. (1967) Life histories of Central American highland birds. Cambridge, Mass.: Nuttall Ornithological Club (No. 7).

Skutch, A. F. (1976) Parent birds and their young. Austin: University of Texas Press.

Slud, P. (1960) Birds of Finca "La Selva", Costa Rica: a tropical wet forest locality. Bull. Amer. Mus. Nat. Hist. 121: 49-148.

Smythe, N. (1990) Abundancia estacional de insectos nocturnos en un bosque Neotropical. Pp.393-402 in E. G. Leigh, A. S. Rand and D. M. Windsor, eds. Ecología de un bosque tropical. Panamá: Smithsonian Tropical Research Institute.

Snow, D. W. (1962a) A field study of the Black and White Manakin Manacus manacus in Trinidad. Zoologica 47: 64-104.

Snow, D. W. (1962b) A field study of the Golden-headed Manakin, Pipra erythrocephala, in Trinidad, W.I. Zoologica 47: 183-198.

Stiles, F. G. (1985) Cambios altitudinales and estacionales en la avifauna de la vertiente atlántica de Costa Rica. Pp.95-103 in F. G. Stiles and P. G. Aguilar F., eds. Primer Symposio de Ornitología Neotropical (14-15 octubre 1983, Arequipa, Perú). Lima: Asociación Peruana para Conservación de la Naturaleza.

Stiles, F. G. (1988) Altitudinal movements of birds on the Caribbean slope of Costa Rica: implications for conservation. Pp.243-258 in F. Almeda and C. M. Pringle, eds. Tropical rainforests: diversity and conservation. San Francisco, CA: California Academy of Sciences.

Stiles, F. G. and Clark, D. A. (1989) Conservation of tropical rain forest birds: a case study from Costa Rica. Amer. Birds 43: 420-428.

Stiles, F. G. and Rosselli, L. (1993) Consumption of fruits of the Melastomataceae by birds: how diffuse is coevolution? Vegetatio 107/108: $57-73$.

Stiles, F. G. and Skutch, A. F. (1989) A field guide to the birds of Costa Rica. Ithaca, NY: Cornell University Press.

Terborgh, J. (1986a) Keystone plant resources in the tropical forest. Pp.330-344 in M. E. Soulé, ed. Conservation biology. Sunderland, U.S.A.: Sinauer Associates.

Terborgh, J. (1986b) Community aspects of frugivory in tropical forests. Pp.371-384 in A. Estrada and T. H. Fleming, eds. Frugivores and seed dispersal. Dordrecht: Dr W. Junk.

Tosi, J. A. (1969) Mapa ecológico de Costa Rica. San José, Costa Rica: Tropical Science Center.

Wheelwright, N. T. (1983) Fruit and the ecology of Resplendent Quetzals. Auk 100: 286301.

Wheelwright N. T., Haber, W. A., Murray, K. G. and Guindon, C. (1984) Tropical fruit eating birds and their food plants: a survey of a Costa Rican lower montane forest. Biotropica 16: 173-192. 
Worthington, A. H. (1990) Comportamiento de forrajeo de dos especies de saltarines en respuesta a la escasez estacional de frutos. Pp.285-304 in E. G. Leigh, A. S. Rand and D. M. Windsor, eds. Ecología de un bosque tropical. Panamá: Smithsonian Tropical Research Institute.

LORETA ROSSELLI

Escuela de Biología, Universidad de Costa Rica

Present address: Apartado Postal 250842, Bogotá, Colombia 